\title{
PARADIGMA IDIOLOGI SISTEM EKONOMI DUNIA
}

\author{
NURHADI \\ Sekolah Tinggi Agama Islam (STAI) Al-Azhar Pekanbaru \\ alhadicentre@yahoo.co.id
}

\begin{abstract}
The paradigm of the capitalist and socialist economic system suggests that the production and consumption and distribution of wealth in principle have been established in accordance with applicable economic laws in the economic practice of society. Economic System is a system that regulates and establish economic relationships between people with a set of institutions in the order of life in the community or state. Almost every country has its own economic system. The paradigm of thought as the choice of economic system applied in a country depends on the mutual agreement of the country, in accordance with the constitution owned, the philosophy and ideology of the state in its economic system. The economic system is a system that regulates the economic conditions of a country in accordance with state conditions of the country itself. The capitalist economic system rests on private and private ownership of the means of production, distribution, and exchange. so that the three main things are full in private hands, the system is oriented to Jewish ideology. The socialist economic system is its economic activities ranging from planning, implementation, and supervision carried out by the government centrally, this system adopts the Christian ideology of religion. Communist economic system is an economic system in which the role of government as a regulator of all sources of economic activity, this system pivots on the ideology of Atheist. Pancasila economic system is a system of economic democracy, this system comes from the ideology of Pancasila. The Islamic economic system is an economic system based on the ideology of Tawheed (aqidah) Islam, Nubuwwah (prophet) Muhammad saw (the obligatory nature of Prophet and Messenger) and Khilafah (leadership) and Ma'ad (result).
\end{abstract}


Nurhadi; Paradigma Idiologi Sistem Ekonomi Dunia

Keyword : Paradigm, Idiology, System, Economy, World

\section{PENDAHULUAN}

Adam Smith menurut ekonom dunia merupakan pemikir ekonom klasik yang meletakkan dasar-dasar sistem ekonomi kapitalis. Para pemikir manhaj ekonomi tradisional mengemukakan bahwa setiap kegiatan ekonomi yang dilaksanakan secara bebas lebih banyak mamfaatnya bagi masyarakat dibandingkan jika diatur atau ikut campur tangan pemerintah (Agustiati, 2015: 153).

Paradigm ini berdasarkan pendapat yang mengemukakan bahwa produksi dan komsumsi serta distribusi kekayaan pada asasnya sudah ditetapkan sesuai hukumhukum ekonomi yang berlaku dalam parktek perekonomian masyarakat. Pemikir mazhab klasik atau tradisional memiliki pendapat tertentu mengenai permasalahan ekonomi yang paling penting dalam masyarakat yakni yang berkaitan dengan masalah pokok yang saling berhubungan kemudian melahirkan suatu metode analisis teoritis. Sebagai contoh hubungan antara nilai dan harga barang, besarnya upah dan besarnya laba, yang ditentukan oleh pasar persaingan. Oleh karenanya pemerintah berperan hanya pada prasarana pekerjaan umum serta jasa-jasa publik saja (Agustiati, 2015: 153).

Para pakar dan ahli mendefenisikan sistem sebagai kesatuan yang terpadu secara holistik yang terdiri dari bagianbagian, dan tiap-tiap bagian memiliki ciri dan batas tersendiri. Suatu sistem pada dasarnya merupakan organisasi besar yang menjalin berbagai subyek / obyek serta perangkat kelembagaan dalam suatu tatanan tertentu. Subyek / obyek pembentuk sebuah sistem dapat berupa orang-orang atau masyarakat yang menggunakan perangkat kelembagaan. Sesungguhnya persoalan-persoalan ekonomi pada hakekatnya adalah masalah transformasi atau pengolahan alat-alat / sumber penentu / pemuas kebutuhan yang berupa factor-faktor produksi, yaitu tenaga kerja, modal, sumber daya alam dan keterampilan menjadi barang dan jasa (Bhudianto, 2012: 1).

Sistem Ekonomi adalah suatu sistem yang mengatur serta menjalin hubungan ekonomi dengan antar manusia dengan seperangkat kelembagaan dalam tatanan kehidupan bermasyarakat atau bernegara. Sistem ekonomi suatu Negara dikatakan bersifat khas (unik) jika berbeda dengan sistem ekonomi yang ada dinegara lain, hal ini bisa dilihat dari tiga aspek, yaitu: (1) Sistem pemilikan sumber daya atau faktor-faktor produksi; (2) keluwesan masyarakat untuk saling berkompetisi satu sama lain dan untuk menerima imbalan atas prestasi kerjanya; dan (3) kadar peranan pemerintah dalam mengatur, mengarahkan dan merencanakan kehidupan bisnis dan 
perekonomian pada umumnya (Farida, 2011: 21).

Hampir setiap negara memiliki sistem ekonomi sendiri. Paradigma pemikiran sebagai pilihan sistem ekonomi yang diterapkan di suatu negara tergantung pada kesepakatan bersama negara tersebut, sesuai dengan undangundang dasar yang dimiliki, falsafah dan ideologi negara dalam sistem perekonomiannya. Sistem Ekonomi juga dapat dikatakan sebagai suatu keseluruhan lembaga-lembaga ekonomi yang diterapkan suatu bangsa / negara dalam rangka mencapai cita-cita kemajuan dan kesejahteraan dalam bernegara dan berbangsa. (Subandi, 2011: 31 dan Bhudianto, 2012: 2).

Upaya yang dilakukan Negara dalam meningkatkan kesejahteraan masyarakat penduduk Negara, selalu melalui dengan mengupayakan peningkatan pertumbuhan ekonomi dan pembangunan. Pertumbuhan ekonomi adalah upaya peningkatan kegiatan ekonomi dalam sistem perekonomian dan pembangunan upaya pengembangan sistem ekonomi (Nurhadi, 2017). Pengembangan sistem ekonomi dan pengembangan identitas negara dan bangsa, juga diiringi dengan sistem non-ekonomi, seperti politiknya, hukumnya, dan sistem sosial budaya (Nurhadi, 2017).

Sebagai pemikir ekonom selalu optimis bahwa kinerja perekonomian global yang berlangsung selalu mengecewakan dan menurun jika dibandingkan dengan yang telah berlalu.
Pertumbuhan ekonomi global menurun dari $3,1 \%$ menjadi $3,0 \%$, harga komoditas terus terkoreksi ke bawah dan ketidakpastian di pasar keuangan semakin meningkat. Kondisi tersebut dipengaruhi oleh pergeseran siklus dan tatanan ekonomi global yang terjadi di sepanjang tahun. Namun direspons dengan kebijakan di berbagai negara sehingga kinerja perekonomian global cenderung membaik di akhir tahun, hal ini dapat mengembalikan optimisme perbaikan ekonomi ditahun depannya (Indonesia, 2013: 2).

Pemahaman tentang sistem perkonomian, yang merupakan suatu desain yang diberlakukan di suatu negara dalam memecahkan persoalan ekonomi, walaupun sampai saat ini belum ada sistem ekonomi yang paripurna, yang mampu menyelesaikan persoalan bangsa khususnya keadilan dan pemerataan bagi kesejahteraan masyarakatnya di suatu Negara (Chaudhry, 2012: 355-356 dan Tho'in, 2015: 118).

Krisis ekonomi dan keuangan global yang terjadi tahun 2008 di Amerika Serikat dan kebangkrutan bank investasi Lehman Brothers telah menggoyahkan perekonomian negara maju hingga intinya. Di Eropa krisis ini bahkan berkembang menjadi krisis perbankan dan pada akhirnya menjadi krisis yang kerap disebut sebagai "krisis euro". Kendatipun berhasil diatasi, namun belum terselesaikan. Ini berdampak ke Indonesia, namun kebijakan ekonomi yang baik dan kokohnya permintaan domestik dan juga 
rendahnya hutang publik, sehingga perekonomian relatuf stabil, terutama dunia perbankan Islam (Roubini, 2016: ix).

Di Eropa gejala ini memfokuskan pada kritik pemikiran neo-liberalisme yang menjadi dasar paradigma kebijakan ekonomi di negara-negara ini beberapa dekade. Menurut pendapat banyak ekonom, "fundamentalisme pasar", pasar keuangan yang tak terkontrol, serta ketidakseimbangan global merupakan faktor penyebab utama krisis yang menyebabkan jutaan orang kehilangan pekerjaannya (Roubini, 2016: ix).

$$
\text { Krisis moneter yang }
$$

menyerang ekonomi Indonesia tahun 1997 merontokkan sektor perbankan modern yang keropos. Hutang semangkin membengkak, hal ini menyulitkan perekonomian Indonesia karena resep-resep penyehatan ekonomi (hutang, pencabutan subsidi dan privatisasi) dari Dana Moneter Internasional (IMF) meluluhkan ekonomi rakyat. Krisis Moneter juga menciptakan suasana ketergantungan ekonomi Indonesia pada kekuatan kapitalis (Supriyanto, 2009: 193).

Pada dasarnya, karakter dasar seorang manusia tidak akan mampu menerima kesengsaraan dan penderitaan si miskin yang menjadi ciri dari dominasi kapitalisme laissez-faire. Hal ini membangunkan konsep baru yaitu system sosialis. Sistem sosialis bukanlah suatu istilah yang monolitik tanpa partikal, akan tetapi telah melahirkan turunan-turunannya, baik dalam bentuk Marxis, maupun pasar, bahkan demokrasi ekonomi, dan lain-lainnya (D.F. Griffith, 1984, 1988: 21).

Seluruh sistem ekonomi yang berlaku pada intinya untuk mensejahterakan masyarakat, ini konsep sekaligus visi misinya sistem tersebut, yaitu kesejahteraan sosial masyarakat, demikian pula sistem kapitalis. Walaupun sebenarnya prinsipnya adalah kebebasan individu namun tujuan akhir kesejahetraan semuanya, sebagaimana pendapat Adam Smith (pelopor dari kapitalisme), adalah untuk mencapai efisiensi perkonomian yang akan membawa kepada kemakmuran dan kesejahteraan bagi rakyat secara keseluruhan, sama halnya dengan sistem sosialis (Trialdi, dkk, 1999: 83).

Manusia sebagai makhluk sosial tentunya sangat tergantung antara satu dengan yang lain dalam segala aspek kehidupannya, baik masalah sosial, ekonomi, politik dan lainya. Manusia juga sebagai khalifah (penguasa) di bumi yang terhmpar luas, yang ini semuanya diciptakan untuk manusia itu sendiri, tentunya manusialah yang berhak mengelola dan mengaturnya dengan akal pikirannya agar dikuasai manusia demi kesejahteraannya dalam memenuhi segala kebutuhan dan keperluannya selama hidup didunia ini (Pangiuk, 2011: 2).

\section{PEMBAHASAN}

A. Terminology Sistem
Ekonomi
Istilah "sistem" berasal dari
perkataan "systema" (bahasa


Yunani), yang dapat diartikan sebagai: keseluruhan yang terdiri dari macam-macam bagian. Istilah "sistem" berasal dari perkataan "systema" (bahasa Yunani), yang dapat diartikan sebagai: keseluruhan yang terdiri dari macam-macam bagian (Supriyanto, 2009: 199 dan Dumairy, 2006: 28).

Menurut Suroso (2014: 7-8). Dilihat dari tujuannya, sistem ekonomi merupakan usaha untuk mengatur pertukaran barang dan jasa yang bertujuan meningkatkan kesejahteraan rakyat. Karena meningkatkan kesejahteraan rakyat itu merupakan salah satu tujuan dari politik nasional, maka dengan demikian sistem perekonomian pada dasrnya merupakan bagian dari sistem politik nasional. Menurut Dumairy (2006: 30), Sistem ekonomi adalah suatu sistem yang mengatur serta menjalin hubungan ekonomi antar manusia dengan seperangkat kelembagaan dalam suatu tatanan kehidupan.

Selanjutnya

dikatakannya pula bahwa suatu sistem ekonomi tidaklah harus berdiri sendiri, tetapi berkaitan dengan falsafah, padangan dan pola hidup masyarakat tempatnya berpijak. Sistem ekonomi sesungguhnya merupakan salah satu unsur saja dalam suatu supra sistem kehidupan masyarakat. Sistem ekonomi merupakan bagian dari kesatuan ideology kehidupan masyarakat di suatu negara. Menurut Gregory Grossman dan M. Manu mengatakan bahwa :"Sistem ekonomi adalah sekumpulan komponen-komponen atau unsurunsur yang terdiri dari atas unit-unit dan agen-agen ekonomi, serta lembaga-lembaga ekonomi yang bukan saja saling berhubungan dan berinteraksi melainkan juga sampai tingkat tertentu yang saling menopang dan mempengaruhi (Grossman, 2015)." Menurut Bapak Ekonomi yaitu Adam Smith (1723 1790): system ekonomi merupakan bahan kajian yang mempelajari upaya manusia memenuhi kebutuhan hidup di masyarakat dalam meningkatkan kesejahteraan (Kinasih, 2011).

\begin{tabular}{llr}
\multicolumn{2}{c}{ Berdasarkan berbagai } \\
macam & pemaparan mengenai \\
sistem ekonomi dari berbagai & \\
sumber maka dapat disimpulkan
\end{tabular}
bahwa sistem ekonomi adalah suatu sistem yang mengatur kondisi perekonomian suatu negara sesuai dengan kondisi kenegaraan dari negara itu sendiri. Setiap negara memiliki sistem perekonomian yang berbeda-beda. Hal itu disebabkan setiap Negara memiliki ideologi, kondisi masyarakat, kondisi perekonomian, serta kondisi SDA yang berbeda-beda. Sistem ekonomi dapat diartikan sebagai kegiatan produksi, konsumsi dan distribusi yang bertujuan untuk memenuhi kebutuhan masyarakat (Nurhadi, 2018).

Sistem tersusun dari seperangkat komponen yang bekerja secara bersama-sama untuk mencapai semua tujuan dari keseluruhan sistem tersebut. Sebuah sistem dapat digambarkan sebagai sebuah kumpulan dari komponen-komonen dimana beberapa dari komponen tersebut saling berhubungan secara tetap 
dalam jangka waktu tertentu (Supriyanto, 2009: 199).

1) Setiap sistem tidak hanya sekedar kumpulan berbagai bagian, unsur atau komponen, melainkan merupakan satu kebulatan yang utuh dan padu.

2) Setiap sistem melakukan kegiatan atau proses mengubah masukan menjadi keluaran.

Pengertian sistem ekonomi mencakup seluruh proses dan kegiatan masyarakat dalam usaha memenuhi kebutuhan hidup atau mencapai kemakmuran. Dalam system ekonomi juga terdapat Elemen sistem ekonomi, yang terdiri atas (Supriyanto, 2009: 199):

1) Unit-unit ekonomi seperti: rumah tangga, perusahaan, serikat buruh, instansi pemerintah dan lembagalembaga lain yang berkaitan dengan kegiatan ekonomi.

2) Pelaku-pelaku ekonomi seperti: konsumen, produsen, buruh, invstor dan pejabatpejabat yang terkait.

3) Lingkungan Sumber Daya Alam (SDA) Dan Sumber Daya Manusia (SDM),

4) Sumber Daya Kapital (SDK), Sumber Daya Teknologi (SDT).

Sedangkan pranata/Institusi Ekonomi sendiri merupakan mekanisme yang mengendalikan proses kegiatan ekonom, yang terdiri dari (Supriyanto, 2009: 199):

1) Norma hidup, seperti norma agama, adat-istiadat, tradisi, etika profesi.
2) Peraturan hidup, seperti konstitusi (UUD), undangundang, peraturan pemerintah

3) (PP), Peraturan Darah (Perda), Keputusan Presiden (Keppres), Surat Keputusan/Surat Edaran Pejabat Resmi, Perjanjianperjanjian Bilateral/ Internasional.

4) Paham Hidup, seperti pandangan hidup, cara hidup, ideologi.

Setiap sistem ekonomi pasti mempunyai tujuan. Tujuan sistem ekonomi suatu negara pada umumnya meliputi empat tugas pokok (Supriyanto, 2009: 199):

1) (1)Menentukan apa, berapa banyak dan bagaimana produk-produk dan jasa-jasa yang dibutuhkan akan dihasilkan.

2) Mengalokasikan produk nasional bruto (PNB) untuk konsumsi rumah tangga, konsumsi masyarakat, penggantian stok modal, investasi.

3) Mendistribusikan pendapatan nasional $(\mathrm{PN}), \quad$ diantara anggota masyarakat: sebagai upah/gaji, keuntungan perusahaan, bunga dan sewa.

4) Memelihara dan meningkatkann hubungan ekonomi dengan luar negeri (Supriyanto, 2009: 200). Sistem perkonomian merupakan sebuah skema yang digunakan suatu negara tertentu di dalam memecahkan persoalan- 
persoalan ekonomi yang dialami oleh negara tersebut, agar persoalan ekonomi itu dapat teratasi, jangan sampai dengan adanya sistem ekonomi justru menambah masalah atau persoalan ekonomi suatu negara, walaupun jika ditinjau, sampai saat ini belum ada sistem ekonomi yang sempurna yang mampu menyelesaikan persoalan bangsa khususnya dalam hal keadilan dan pemerataan bagi masyarakatnya yang ada (Muhammad Tho'in, 2015: 120).

\section{B. Sistem Ekonomi Kapitalis (Idiologi Yahudi)}

Sistem ekonomi kapitalis bersandar kepada pemilikan pribadi maupun swasta terhadap alat-alat produksi, kegiatan distribusi, maupun pertukaran. Sehingga tiga hal utama tersebut berada penuh di tangan swasta. Sistem ekonomi kapitalis mendominasi secara keseluruhan dari sistem ekonomi yang dianut oleh negara-negara di dunia. Dimana, di dalam sistem ekonomi kapitalis ini, suatu produksi maupun perdagangannya lebih dominan dilakukan bersifat individualistis atau pribadi. Individu serta perusahaan atau bahkan melalui badan usaha swasta atau korporasi, berupa bantuan modal yang sebelumnya telah diakumulasikan, tetapi yang lebih banyak terjadi dengan menggunakan modal usaha dari pinjaman berbunga, mendapatkan keuntungan atau laba serta membangun suatu kerajaan untuk diri mereka sendiri dengan jalan mempekerjakan orang banyak dengan memberikan imbalan upah (Chaudhry, 2012: 355-356).

Sistem ekonomi kapitalis menjadi system ekonomi yang mendominasi dari system ekonomi yang dipakai negara-negara saat ini. Meskipun dengan perkembangan teknologi dan informasi atau IT yang begitu dahsyat saat ini, boleh dikatakan tidak ada sistem ekonomi kapitalis murni, karena di negaranegara kapitalis lebih sosialis dibandingkan dengan negara-negara yang menggunakan system ekonomi sosialis itu sendiri. (Asy'arie, Disampaikan dalam Focused Group Discussion Matakuliah Sejarah Pemikiran Ekonomi Islam, Pascasarjana UIN Sunan Kalijaga, Kamis, 15 Desember 2016 sebagaimana dikutip Muhammad Tho'in (2015: 120).

Menurut Winardi (1990) Sistem ekonomi kapitalis ini, merupakan suatu system ekonomi di mana hak milik pribadi atas alat-alat produksi, kegiatan distribusi, serta pemanfaatannya untuk mencapai laba dalam kondisi maupun situasi yang sangat kompetitif, menjadi ciri utama dalam system ini. Jika kita melihat sejarah, kapitalisme dibangun dari buah pemikiran tokoh ekonomi besar yaitu Adam Smith, dia merupakan tokoh dari mazhab klasik (Tho'in, 2015: 120).

Para ahli ekonomi dunia mayoritas sepakat bahwa hasil dari pemikiran mazhab klasik inilah yang menjadi dasar dari sistim ekonomi, yaitu sistem ekonomi kapitalis (Agustiati, 2009: 152). Dasar pemikiran teori yang dikeluarkan oleh Adam Smith ini dapat bertahan 
hingga terjadinya depressi ekonomi pada tahun 1929, di mana pada saat itu pemikir ekonomi lainnya, yaitu Keyness mengeluarkan gagasannya, dia tampil serta berhasil mengungkapkan sebuah teori dan gagasan bahwa sistem ekonomi yang baru dan lebih baik dapat dibangun. Pemikiran Keyness ini atau Keynesian membutuhkan adanya intervensi serta campur tangan dari pemerintah dalam menentukan kebijakan-kebijakan ekonomi. Hal inilah yang menjadi awal jatuhnya sistem ekonomi kapitalis saat itu, akan tetapi dengan berjalan waktu selama lebih kurang 30 tahun terjadi krisis yang besar yang melanda dunia, berupa krisis minyak dunia tepatnya pada tahun 1973, system ekonomi kapitalis yang jatuh kembali tampil sebagai sistem ekonomi dengan nama baru, yaitu neoliberalisme (Agustiati, 2009: 152).

1. Pilar-pilar sistem ekonomi kapitalis Sistem ekonomi kapitalis ini menyadarkan diri secara penuh kepada hal-hal di bawah ini:

a) Private property atau hak milik swasta (Pengakuan yang luas atas hak-hak pribadi) (Agustiati, 2009: 155-156).

b) The invisibel hand atau dibina oleh tangan tak terlihat (Campur tangan pemerintah diusahakan sekecil mungkin. "The Invisible Hand" yang mengatur perekonomian menjadi efisien) (Agustiati, 2009: 155). c) Idividualisme ekonomi (Paham individualisme didasarkan materialisme, warisan zaman Yunani Kuno (disebut hedonisme) (Agustiati, 2009: 156).

d) Free market kompetition atau persaingan dan pasar bebas(Agustiati, 2009: 156).

e) Pemilikan alat-alat produksi di tangan individu

f) Inidividu bebas memilih pekerjaan/ usaha yang dipandang baik bagi dirinya.

g) Pasar berfungsi memberikan "signal" kepada produsen dan konsumen dalam bentuk harga-harga.

h) Motif yang menggerakkan perekonomian mencari laba

i) Manusia dipandang sebagai mahluk homoeconomicus, yang selalu mengejar kepentingan (keuntungan) sendiri (Supriyanto, 2009: 200).

2. Kerangka dasar sistem ekonomi kapitalis (Agustiati, 2009: 156-159).

a) Kelangkaan sumbersumber ekonomi. Benturan antara kebutuhan manusia yang tidak terbatas dengan terbatasnya (langkanya) barang-barang ekonomi yang tersedia dalam usaha menjembatani hal 
tersebut adalah dengan jalan menambah jumlah produksi barang dan jasa sebanyakbanyaknya agar kebutuhan manusia yang tidak terbatas dapat diperkecil, adanya kelangkan sumbersumber ekonomi maka para ekonomi kapitalis melihat 3 pokok permasalahan ekonomi yang harus dipecahkan (1) Apa yang harus diproduksi dan dalam jumlah berapa? pertanyaan pertama ini secara umum menyangkut barang dan jasa yang dibutuhkan manusia, dan secara khusus menyangkut singkronisasi antara kebutuhan manusia dengan daya belinya. (2) Bagaimana sumbersumber ekonomi (faktorfaktor produksi) yang tersedia harus dipergunakan untuk memproduksi barangbarang tersebut? Jawaban permasalahan yang kedua ini adalah menyangkut tentang teknik produksi, yaitu bagaimana mengkombinasikan faktor-faktor produksi untuk mendapatkan output yang optimal. (3) Untuk siapa barang tersebut di produksi; atau bagaimana barang- barang tersebut di bagikan di antara warga masyarakat? jawaban atas permasalahan yang ketiga ini pakar ekonomi kapitalis menjawabnya dengan pembahasan teori harga, yaitu peranan harga dalam menentukan produksi-

komsumsidistribusi

(Boediono, 1993). Meskipun jawaban permasalahan di atas pada akhirnya harus berbenturan dengan tingkat permintaan konsumen, di mana tingkat permintaan konsumen dipengaruhi oleh banyak faktor, sehingga tingkat produksi secara riil bukanlah produksi sebanyakbanyaknya karena dapat mengakibatkan inefisiensi ekonomi dan ketidak seimbangan pasar (market disequilibrium) akan tetapi philosopi pemecahan masalah (problem solving) ekonomi dengan cara seperti ini menentukan bagaimana sistem ekonomi kapitalis melihat hakekat permasalahan ekonomi. Dengan cara pandang seperti ini, maka bagi sistem ekonomi kapitalis, solusi ekonomi yang harus ditempuh secara mikro adalah peningkatan produksi 
sebanyak-banyaknya,

dan secara makro mengejar pertumbuhan ekonomi setinggitingginya (Tho'in, 2015: 121).

b) Pandangan tentang nilai barang. Dalam sistem ekonomi kapitalis, nilai merupakan sesuatu yang sangat penting. Karena nilai merupakan suatu sarana untuk melihat faedah atau kegunaan suatu barang dan jasa, juga untuk menentukan kemampuan produsen dan konsumen. Ada dua kategori tentang nilai barang dan jasa yaitu yang berkaitan dengan nilai kegunaan suatu barang bagi individu yang disebut nilai guna (utility value), dan yang berkaitan dengan nilai suatu barang terhadap barang lainnya disebut nilai tukar (exchange value) (Agustiati, 2009: 157-158).

c) Peranan harga dalam sistem ekonomi kapitalis. Harga di dalam sistem ekonomi kapitalis mempunyai peranan dalam kegiatan produksi, kegiatan konsumsi, serta kegiatan distribusi melalui struktur harga (Tho'in, 2015: 122 dan Agustiati, 2009: 159).

1) Peranan harga dalam kegiatan produksi. Peranan

harga dalam

bidang produksi, harga

menentukan siapa

saja produsen

yang boleh masuk

dalam area

produksi dan

siapa saja yang

tidak boleh masuk

atau keluar dari

area produksi.

Struktur harga

dengan sendirinya

akan megatur dan

menyaring

produsen

berdasarkan

tingkat

kemampuan

produsen dalam

menanggung

biaya produksi

yang meliputi

biaya pengadaan

barang kemudian

struktur harga

juga akan

menyaring para

produsen yang tetap bertahan di

area produksi,

ketika beban

biaya produksi

masih dapat

ditanggung

produsen yang

mungkin

disebabkan oleh

masih adanya

persediaan modal

yang dimiliki

produsen 


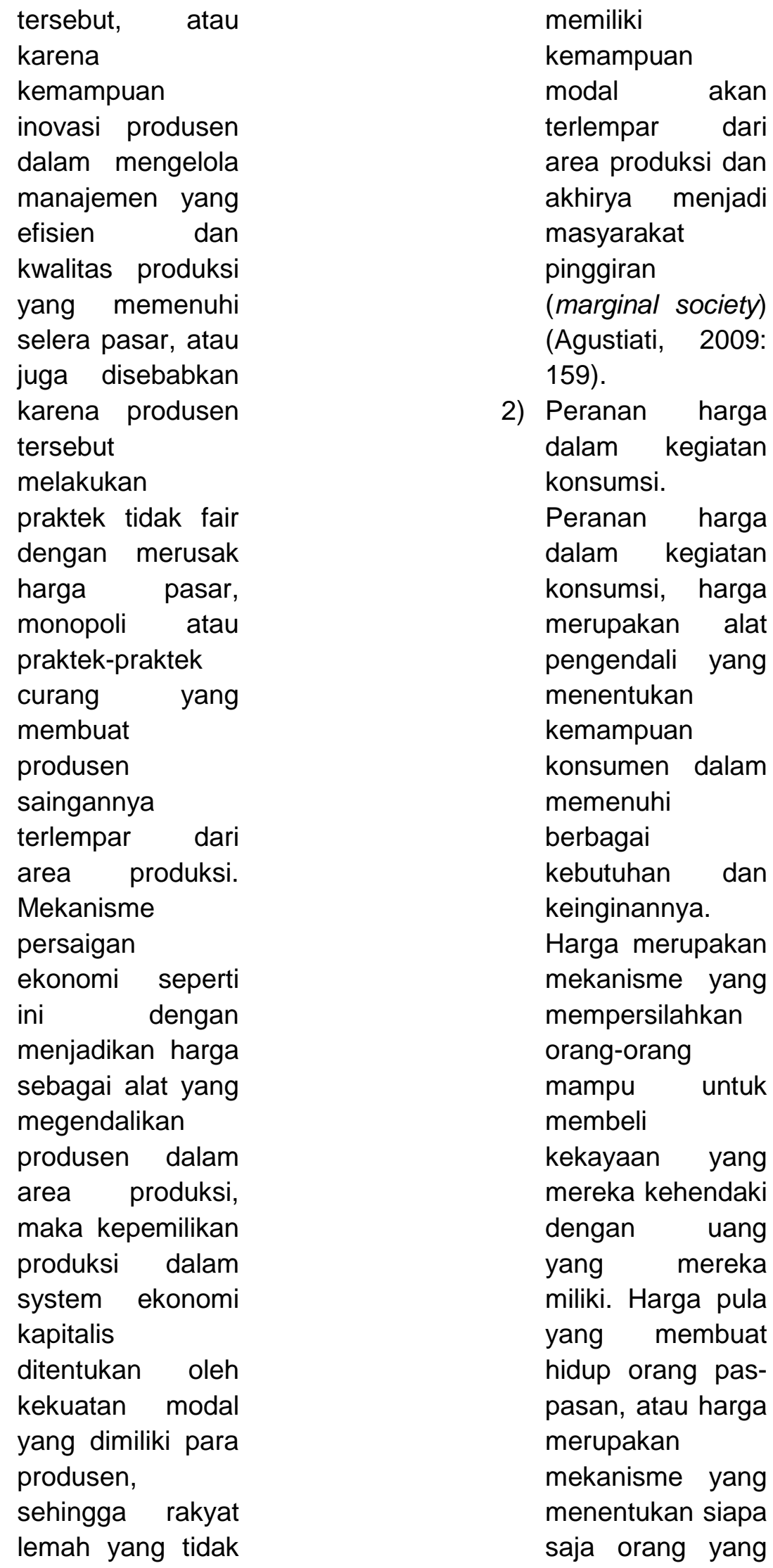




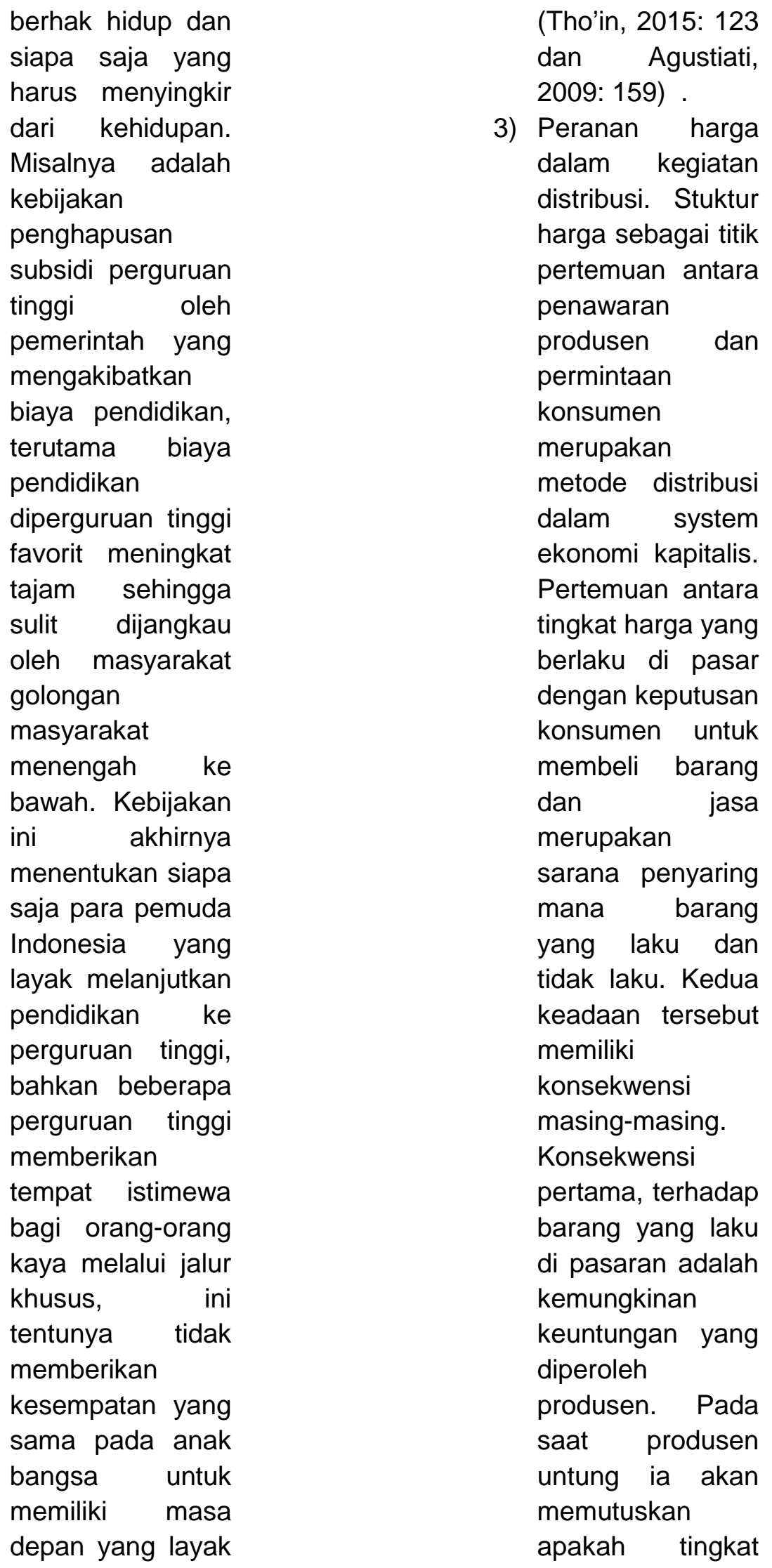


produksi

(penawaran) tetap

ataukah

dinaikkan.

Konsekwensi

kedua, terhadap

barang yang tidak

laku di pasaran

adalah

kemungkinan

kerugian yang

dialaminya maka

ia tetap

melakukan

produksi

meskipun dengan

menurunkan

tingkat

produksinya.

Sebaliknya, ketika produsen tidak

mampu lagi

menanggung

kerugian, maka

baginya harus

menghentikan

produksi atau

dengan kata lain

menutup

usahanya.

Kombinasi dua

konsekwensi

tersebut

menghasilkan

atau mengubah

laju produksi

sebelumnya.

Adapun yang dimaksud dengan laju produksi menyangkut tiga hal, yaitu barang apa saja yang diproduksi, berapa banyak

diproduksi, dan

untuk siapa

barang tersebut

diproduksi. Bagi

produsen, barang

yang diproduksi

adalah barang

dan jasa yang

menghasilkan

keuntungan, yakni

barang yang laku

di pasaran

(Agustiati, 2009: 160-161).

3. Kelebihan sistem ekonomi kapitalis sebagai berikut yang dirilis oleh Amazine.coOnline Popular Knowledge Tahun 2017 adalah sebagai berikut (Tho'in, 2015: 124):

a) Kapitalisme mendorong pertumbuhan ekonomi dengan memfasilitasi kompetisi terbuka di pasar.

b) Sistem ini menyediakan individu kesempatan lebih baik untuk meningkatkan pendapatan mereka dan dengan demikian mencapai pertumbuhan ekonomi.

c) Hasil dari kapitalisme adalah system ekonomi yang terdesentralisasi. Faktor ini dianggap sebagai salah satu kelebihan terbesar kapitalisme.

d) Dalam perekonomian yang terdesentralisasi, individu memiliki lebih 
banyak pilihan dalam bisnis.

e) Mereka terpapar dengan kompetisi dan harus menghadapi tantangan yang berbeda serta dituntut menemukan solusi untuk unggul dalam kompetisi.

f) Kerja keras amat dihargai dalam ekonomi kapitalis. Pengusaha yang memiliki kinerja baik dan mampu terus berinovasi akan memenangkan

persaingan (Supriyanto, 2009: 200)..

g) Kapitalisme membentuk ekonomi dimana konsumen mengatur pasar. Banyak yang menganggap ini sebagai salah satu kekuatan terbesar ekonomi kapitalis. Sebuah pasar yang kompetitif akan merangsang inovasi dan mendorong munculnya bermacam produk dan layanan. Hal ini membuat konsumen memiliki lebih banyak pilihan serta mendorong orang untuk mencapai kebebasan finansial.

4. Kekurangan sistem ekonomi kapitalis yang dirilis oleh Amazine.co-Online Popular Knowledge Tahun 2017 adalah sebagai berikut:

a) ekonomi kapitalis dapat menimbulkan persaingan tidak sehat (Supriyanto, 2009: 201). b) Kapitalisme membuat ekonomi yang berorientasi pada uang. Perusahaan bisnis akan melihat ekonomi dengan titik pandang materialistik.

c) Profit dipandang menjadi tujuan bisnis utama dengan raksasa bisnis mengambil alih perusahaan-perusahaan kecil.

d) Tenaga kerja juga dikompensasi dengan tujuan tunggal agar memiliki produktivitas lebih tinggi.

e) Sebagian ekonom percaya bahwa kapitalisme memicu penipisan sumber daya alam karena dieksploitasi untuk menjaga pertumbuhan ekonomi yang berkesinambungan.

f) Kapitalisme juga diyakini menyebabkan distribusi kekayaan yang tidak adil dengan kekayaan dan kekuasaan hanya dikuasai oleh segelintir orang (Tho'in, 2015: 124).

\section{Sistem Ekonomi Sosialis (Idiologi Nasrani)}

Sistem ekonomi sosialis berkebalikan dengan sistem ekonomi kapitalis. Dimana, di dalam sistem ekonomi ini kegiatan-kegiatan ekonominya mulai dari perencanaan, pelaksanaan, serta pengawasan dilakukan oleh pemerintah secara terpusat. Sehingga setiap individu tidak berhak atas kekayaan yang 
dimilikinya, karena alat-alat produksi, kegiatan distribusi, maupun pertukaran dilakukan oleh pemerintah dengan tujuan kesejahteraan masyarakat bersama (Tho'in, 2015: 119).

Sistem ekonomi ini merupakan bentuk resistensi dari sistem ekonomi sebelumnya yaitu sistem ekonomi kapitalis. Karena system ekonomi kapitalis dituding menjadi penyebab tidak tercapainya suatu kesejahteraan masyarakat yang merata. Sistem ekonomi sosialis merupakan kebalikan dari system ekonomi kapitalis, yang mana menyerahkan segala siklus ekonomi sepenuhnya kepada mekanisme pasar yang ada. Sedangkan untuk sistem ekonomi sosialis, di mana pemerintah sangat memiliki peran sangat besar di dalam mengelola roda perekonomian dari hulu hingga hilir dalam rantai perekonomian di masyarakat (Tho'in, 2015: 125)

Sistem ekonomi sosialis bukan berarti tidak memberikan kebebasan individu dalam kegiatan ekonomi, individu tetap diberikan kebebasan dalam melakukan aktivitas ekonomi tetapi sangat terbatas sekali, serta dengan adanya campur tangan pemerintah yang sangat besar. Pemerintah melakukan campur tangan demi terwujudnya kemakmuran masyarakat bersama, tetapi di sisi lain kepemilikan individu yang dibatasi menyebabkan kreativitas individu menurun karena semangat untuk berkarya di bayangbayangi oleh pemerintah untuk kemakmuran bersama. Karena sistem ekonomi sosialis ini memiliki pandangan bahwa suatu kemakmuran pribadi atau individu hanya dapat terwujud jika berlandaskan kemakmuran secara bersama-sama. Sehingga konsekuensi yang harus dipertaruhkan ialah penguasaan dan kepemilikan atas aset-aset ekonomi maupun terhadap faktor-faktor produksi yang ada sebagian besarnya adalah kepemilikan untuk sosial (Tho'in, 2015: 125). .

1. Ciri-ciri sistem ekonomi sosialis:
a) Lebih mengutamakan kebersamaan atau kolektivitas;
b) Pemerintah memiliki peran sangat besar (Supriyanto, 2009: 201).
c) Sifat manusia dalam sistem ini ditentukan oleh pola produksi;
d) Hak milik individu tidak diakui.

2. Prinsip dasar sistem ekonomi sosialis menurut Caporaso (2008), adalah sebagai berikut:

a) Pemilikan harta oleh negara seluruh bentuk produksi dan sumber pendapatan menjadi milik masyarakat secara keseluruhan. Hak individu untuk memiliki harta atau memanfaatkan produksi tidak diperbolehkan;

b) Kesamaan ekonomi sistem ekonomi 


$$
\begin{aligned}
& \text { sosialis menyatakan, } \\
& \text { (walaupun sulit } \\
& \text { ditemui disemua } \\
& \text { negara komunis) } \\
& \text { bahwa hak-hak } \\
& \text { individu dalam suatu } \\
& \text { bidang ekonomi } \\
& \text { ditentukan oleh } \\
& \text { prinsip kesamaan. } \\
& \text { Setiap individu } \\
& \text { disediakan kebutuhan } \\
& \text { hidup menurut } \\
& \text { keperluan masing- } \\
& \text { masing; } \\
& \text { c) Keseluruhan negara } \\
& \text { diletakkan di bawah } \\
& \text { peraturan kaum } \\
& \text { buruh, yang } \\
& \text { mengambil alih } \\
& \text { semua aturan } \\
& \text { produksi dan } \\
& \text { distribusi (Tho'in, } \\
& \text { 2015: 125). }
\end{aligned}
$$

3. Kelebihan sistem ekonomi sosialis:

a) Semua kegiatan ekonomi dikendalikan oleh pemerintah, sehingga pemerintah mudah melakukan control atau pengawasan;

b) Tidak ada kesenjangan ekonomi yang mencolok di antara anggota masyarakat;

c) Pemerintah mudah dalam mengatur dan melakukan pembentukan harga pasar atas barang dan jasa.
4. Kekurangan sistem ekonomi sosialis:

a) Melemahkan bahkan mematikan inisiatif dan kreativitas individu;

b) Seringnya terjadi prakteik monopoli yang merugikan masyarakat;

c) Masyarakat tidak memiliki kebebasan di dalam memiliki sumber-sumber daya yang ada (Tho'in, 2015: 126 dan Supriyanto, 2009: 201).

\section{Sitem Ekonomi Komunis} (Idiologi Ateis)

Menurut Prof. W. Banning dalam Heden daagshe Sociale Bewegingen pada tahun 1948, dengan terbentuknya Negara Komunis Rusia, berarti kurang dari seperenam dari manusia diseluruh dunia memegang tegampiruh faham dari Karlmax. Pada tahun 1979, dengan berdirinya Republik Rakyat Cina dibawah pimpinan Mao Tze Tung yang menguasai kurang lebih hampir 700 miliun manusia, jumlah pengikut Marxisme hampir mencapai sepertiga penduduk dunia. Pada masa sekarang yang jumlah penduduknya bertambah besra jumlah kaum komunis sudah melebihi separuh penduduk dunia. Namun, pertambahan jumlah pengikut itu buka berarti menimbulkan perpecahan. Tidak pula bahwa di luar kedua negara, tidak ada lagi manusia atau bangsa- 
bangsa lain yang menganut faham Marxisme, seperti di Moskow umpamanya. Berbagai organisasi komunis di dunia mengaku bahwa mereka pengikut Marxisme, sedangkan Lenin dan Stalin dengan negara komunisnya di Rusia, telah menyimpang dari ajaran Marxisme yang sebenarnya (Al-Kaaf: 2012).

Kampiun Komunis adalah Karl Marx. Sosok amat membenci Kapitalisme ini merupakan korban saksi sejarah, betapa ia melihat para anak-abak dan wanita-wanita termasuk keluarganya yang dieksploitir para kapitalis sehingga sebagian besar dari mereka terserang penyakit TBC dan tewas, karena beratnya penderitaan yang mereka alami. Sementara hasil jerih payah mereka dinikmati oleh para pemilik sumber daya (modal) yang disebutnya kaum Borjuis (Wiranata: 2018). Kata Komunisme secara historis sering digunakan untuk menggambarkan sistem-sistem sosial di mana barang-barang dimiliki secara bersama-sama dan distribusikan untuk kepentingan bersama sesuai dengan kebutuhan masing-masing anggota masyarakat. Produksi dan konsumsi berdasarkan motto mereka : from each according to his abilities to each according to his needs. (dari setiap orang sesuai dengan kemampuan, untuk setiap orang sesuai dengan kebutuhan) (Wiranata: 2018).

Tata ekonomi serba terpimpin dengan perencanaan produksi dan pengawasan yang ketat oleh pemerintah pusat ini memang dapat menghindari beberapa kelemahan dari sistem ekonomi serba bebas.
Negara-negara komunis ada juga yang mengalami perkembangan ekonomi yang pesat. Negara komunis menjadi negara totaliter, dengan diktatur Partai Komunis, dimana tidak ada demokrasi atau kebebasan lagi (T. Gilarso: 2014).

Sistem ekonomi komunis adalah suatu sistem perekonomian di mana peran pemerintah sebagai pengatur seluruh sumbersumber kegiatan perekonomian. Setiap orang tidak diperbolehkan memiliki kekayaan pribadi, sehingga nasib seseorang bisa ditentukan oleh pemerintah. Semua unit bisnis mulai dari yang kecil hingga yang besar dimiliki oleh pemerintah dengan tujuan pemerataan ekonomi dan kebersamaan. Namun tujuan sistem komunis tersebut belum pernah sampai ke tahap yang maju, sehingga banyak negara yang meninggalkan sistem komunisme tersebut. Sistem ekonomi komunis, kita dapati pada berbagai negara seperti di Rusia dan RRC. Dalam sistem perekonomian komunis peranan pasar untuk menentukan arah produksi hamper tidak ada. Bila sistem perekonomian kapitalisme dapat kita sebut ekonomi pasar, maka sistem ekonomi komunis adalah ekonomi perintah, yang bersifat totaliter dengan putusan-putusan ekonomi dibuat oleh pusat. Dalam sistem ekonomi komunis negaralah yang menerangkan atau menetapkan pada orang-orang perseorangan (Suaedih, dkk, 2016: 1):

1) Dimana harus bekerja

2) Pekerjaan apa yang harus dipilih 
3) Apa yang harus dimakan

4) Apa yang harus dihasilkan

5) Berapa tinggi harga harus di tetapkan

6) Bagaimana menanam modal simpanan

Gambaran

sistem

perekonomian komunis nampak dengan jelas dengan praktek ekonomi di Rusia. Untuk jelasnya kita kutip pendapat beberapa ilmuwan. Menurut Dr. Muhammad Hatta sistem perekonomian Rusia itu merupakan suatu perekonomian totaliter yang dikuasai sama sekali oleh negara. Seluruh perekonomian dipimpin dari pusat menurut rencana. Produksi, konsumsi, dan distribusi di atur dengan peraturan dan tidak ada tempat privateenterprise. Konkurensi tidak ada, hanya dengan perlombaan bekerja untuk memperoleh sistem danhasil terbaik.

Lebih tegas lagi mengenai sistem perekonomian ini, adalah uraian yang diberikan oleh Dr. Mr. T.S.G.Mulia, mengenai dasarnya yaitu (Suaedih, dkk, 2016: 2 da AshShadr, 2012: 80):

1) Hak milik seseorang dihapuskan. Tanah-tanah, perusahaan, peternakan, perniagaan dengan lainkata semua alat-alat produksi jadi milik negara atau pemerintah. Yang tinggal milik sendiri hanya pakaian, perabot-perabot, upah, gaji dan untuk anggota Kolchos (koperasi yang di dirikan dalam hampir segala lapangan ekonomi)
2) Rumah yang didiaminya juga: $\quad$ yang menentukan rupa kerja untuk tiaptiap orang dan membagikerja ialah pemerintah. Seorang tidak diperbolehkan memilih pekerjaannya

3) Segala lapangan ekonomi dikuasai oleh pemerintah dan diatur menurut rencana yang ditetapkan untuk beberapa tahun, biasanya untuk 5 tahun.

4) Industri merupakan suatu perusahan besar yang melingkungi seluruh negara dan dikemudikan oleh pemerintah dengan alatalatnya. Persediaan, cara menghasilkan, memutar dan mengedarkan barang-

barang, dilakukan oleh pemerintah sendiri.

5) Perniagaan dalam negeri diurus oleh koperasi-koperasi yang mempunyai tokoh-tokoh besar, pasar-pasar tidak ada, begitupun golongan

perantara. Hanya

dikampung-kampung

diperbolehkan tukar-menukar dengan langsung yaitu diantara orang-orang yang menghasilkan dan yang membutuhkan.

6) Perniagaan luar negeri dirus oleh pemerintah sendiri dengan pimpinan komisaris rakyat untuk urusan itu. Dinegara-negara luar ditempatkan pegawaipegawai urusan dagang yang meberikan perantaraan

dalam hal menjual dan 
membeli barang ekspor dan impor diatur dengan teliti dan diawasi dengan jalan keras.

7) Pengangkutan di darat, dilaut dan di udara, semuanya kepunyaan pemerintah.

Sistem ekonomi komunis mempunyai ciri-ciri sebagai berikut :

1) Semua sumber daya ekonomi dimiliki dan dikuasai oleh negara.

2) Seluruh kegiatan ekonomi harus diusahakan bersama. Semua perusahaan milik Negara sehingga tidak ada perusahaan swasta.

3) Segala keputusan mengenai jumlah dan jenis barang ditentukan oleh pemerintah.

4) Harga-harga dan penyaluran barang dikendalikan oleh negara.

5) Semua warga masyarakat adalah karyawan bagi negara.

Adapun Negara-Negara Yang

Menganut Sistem Ekonomi Komunisme yaitu (Suaedih, dkk, 2016: 3):

1) Republik Rakyat Tiongkok

2) Transnistia

3) Kuba

4) Korea Utara

5) Laos

6) Vietnam

Adapun kebaikan dan kelebihan dari Sistem Ekonomi Komunis adalah Disediakannya kebutuhan pokok. Setiap warga negara disediakan kebutuhan pokoknya, termasuk makanan dan minuman, pakaian, rumah, kemudahan fasilitas kesehatan, serta tempat dan lain-lain. Setiap individu mendapatkan pekerjaan dan orang yang lemah serta orang yang cacat fisik dan mental berada dalam pengawasan Negara. Didasarkan oleh perencanaan Negara. Semua pekerjaan dilaksanakan berdasarkan perencanaan Negara Yang sempurna, diantara produksi dengan penggunaannya. Dengan demikian masalah kelebihan dan kekurangan dalam produksi seperti yang berlaku dalam System Ekonomi Kapitalis tidak akan terjadi. Produksi dikelola oleh Negara. Semua bentuk produksi dimiliki dan dikelola oleh Negara, sedangkan keuntungan yang diperoleh akan digunakan untuk kepentingan-kepentingan Negara. Pemerintah lebih mudah mengendalikan inflasi, pengangguran dan masalah ekonomi lainnya. Pasar barang dalam negeri berjalan lancar Pemerintah dapat turut campur dalam hal pembentukan harga Relatif mudah melakukan distribusi pendapatan Jarang terjadi krisis ekonomi.

Sistem Ekonomi komunis mempunyai kelemahan sebagai berikut (Suaedih, dkk, 2016: 4) :

1) Sulit melakukan transaksi. Tawar-menawar sangat sukar dilakukan oleh individu yang terpaksa mengorbankan kebebasan pribadinya dan hak terhadap harta milik pribadi hanya untuk mendapatkan makanan sebanyak dua kali. Jual beli sangat terbatas, demikian pula masalah harga juga ditentukan oelh pemerintah, oleh karena itu 


\begin{tabular}{lrr} 
stabilitas & \multicolumn{2}{c}{ perekonomian } \\
Negara sosialis & lebih \\
disebabkan & tingkat & harga \\
ditentukan oleh & Negara, \\
bukan ditentukan & oleh \\
mekanisme pasar. &
\end{tabular}

2) Membatasi kebebasan. Sistem tersebut menolak sepenuhnya sifat mementingkan diri sendiri, kewibawaan individu yang menghambatnyadalam memperoleh kebebasan berfikir serta bertindak, ini menunjukkan secara tidak langsung system ini terikat kepada system ekonomi dictator. Buruh dijadikan budak masyarakat yang memaksanya bekerja seperti mesin.

3) Mengabaikan pendidikan moral. Dalam system ini semua kegiatan diambil alih untuk mencapai tujuan ekonomi, sementara pendidika moral individu diabaikan. Dengan demikian, apabila pencapaian kepuasan kebendaan menjadi tujuan utama dan nilai-nilai moral tidak diperhatikan lagi.

\section{E. Sitem Ekonomi Pancasila (Idiologi Pancasila)}

Pidato yang diucapkan oleh wakil presiden $\mathrm{RI}$ dalam konferensi ekonomi di Yogyakarta pada tanggal 3 febuari 1946 dikatakan bahwa dasar politik perekonomian $\mathrm{RI}$ terpancang dalam UUD 1945 dalam bab kesejahteraan sosial pasal 33 (Bawazier, 2017: 242 dan
Purwandaya: 2017). Sementara itu Sumitro Djojohadikusumo dalam pidatonya dihadapan "School of Advanced International Studies" Washington D.C tanggal 22 Febuari 1949 juga menegaskan bahwa yang dicita-citakan ialah suatu macam ekonomi campuran yaitu lapanganlapangan tertentu akan dinasionaliasi dan dijalankan oleh pemerintah, sedangkan yang lainnya akan terus terletak dalam lingkungan usaha partekelir. Meskipun system perekonomian Indonesia sudah cukup jelas dirumuskan oleh tokohtokoh ekonomi Indonesia yang sekaligus menjadi tokoh pemerintahan pada awal republic Indonesia berdiri, dalam perkembangannya pembicaraan tentang system perekonomian Indonesia tidak hanya berkisar pada sistem ekonomi campuran, tetapi mengarah pada suatu bentuk baru yang disebut system ekonomi Pancasila. Sistem Ekonomi Pancasila (SEP) menurut Mubyarto (2007) adalah "ekonomi yang dijiwai oleh ideology Pancasila, yaitu sistem ekonomi yang merupakan usaha bersama berasaskan kekeluargaan dan kegotong-royongan nasional' (Purwandaya: 2017 dan Pasaribu, 2017: 6).

Sistem Ekonomi pancasila yang menjadi sumber ideologi Bangsa Indonesia yaitu Pancasila membawa keharusan untuk dijadikan dasar atau pedoman dalam kehidupan berbangsa dan bernegara. Sistem ekonomi Pancasila yang dimili Indonesia kadang disebut juga sebagai demokrasi ekonomi. Dijelaskan oleh 
Latief (2004) sebagaimana dikutip Pasaribu bahwa "demokrasi ekonomi yang menjadi dasar pelaksanaan pembangunan dan yang meliputi ciri-ciri positif maupun negatif yang harus dihindarkan. Garis-garis Besar Haluan Negara yang merupakan pedoman bagi kebijaksanaan pembangunan di bidang ekonomi Indonesia berbunyi: "pembangunan ekonomi yang didasarkan pada Demokrasi Ekonomi menentukan bahwa masyarakat harus memegang peran aktif dalam kegiatan pembangunan (Purwandaya: 2017, Suroso: 2004 dan Pasaribu, 2017: 7).

Demokrasi Ekonomi memiliki ciri-ciri sebagai berikut:

1) Perekonomian disusun sebagai usaha bersama berdasar atas asas kekeluargaan.

2) Cabang-cabang produksi yang penting bagi Negara dan menguasai hajat hidup orang banyak dikuasai oleh Negara.

3) Bumi, air dan kekayaan alam yang terkandung di dalamnya dikuasai oleh engara dan digunakan untuk sebesarbesar kemakmuran rakyat.

4) Sumber-sumber kekayaan dan keuangan engara digunakan dengan permufakatan

Lembagalembaga

5) Perwakilan Rakyat, serta pengawasan terhadap kebijaksanaannya ada pada Lembagalembaga

Perwakilan Rakyat pula.
6) Warga negara memiliki kebebasan dalam memilih pekerjaan yang dikehendaki serta mempunyai hak akan pekerjaan dan penghidupan yang layak.

7) Hak milik perorangan diakui dan pemanfaatannya tidka boleh bertentangan dengan kepentingan masyarakat.

8) Potensi, inisiatif dan daya kreasi setiap warga Negara diperkembangkan

sepenuhnya dalam batasbatas yang tidak merugikan kepentingan umum.

9) Fakir miskin dan anak-anak etrlantar dipelihara oleh Negara (Rintuh: 2005 dan Pasaribu, 2017: 7).

Dalam demokrasi ekonomi harus dihindarkan ciri-ciri negative sebagai berikut:

1) Sistem Free fight liberalism yang menumbuhkan eksploitasi terhadap manusia dan bangsa lain yang dalam sejarahnya di Indonesia telah menimbulkan dan mempertahankan kelemahan structural posisi Indonesia dalam ekonomi dunia.

2) Sistem etatisme dalam mana Negara beserta aparatur ekonomi Negara bersifat dominan serta mendesak dan mamtikan potensi dan daya kreasi unit-unit ekonomi di luar sektor Negara.

3) Pemusatan kekuatan ekonomi pada suatu kelompok dalam bentuk monopoli yang merugikan 
masyarakat (Rintuh: 2005 dan Pasaribu, 2017: 7).

Sistem ekonomi Indonesia yang dikenal sebagai Demokrasi Ekonomi adalah Sistem Ekonomi yang dijalankan oleh Indonesia. Sistem tersebut juga ada yang menyebutnya sebagai sistem ekonomi Pancasila. Pancasila meurpakan kepribadian dan pandangan hidup bangsa, maka sistem ekonomi Indonesia pun lebih tepat jika didasarkan pada nilai-nilai yang terkandung dalam sila-sila Pancasila. Mubyarto sebagaimana dikutip Pasaribu mengatakan bahwa, apa yang disebut oleh presiden Suharto tentang sistem ekonomi koperasi sebagai sistem ekonomi Indonesia itu, tidaklah berbeda dengan system ekonomi Pancasila (Swasono: 2005 dan Pasaribu, 2017: 7).

Menurut Mubyarto (2007) dan Rintuh (2005) sebagaimana dikutip Pasaribu, Sistem Ekonomi Pancasila memiliki ciriciri sebagai berikut:

1) Roda perekonomian digerakkan oleh rangsangan ekonomi, sosial dan moral;

2) Kehendak kuat dari seluruh masyarakat ke arah keadaan kemerataan sosial (egalitarianism), sesuai asasasas kemanusiaan;

3) Prioritas kebijakan ekonomi adalah penciptaan perekonomian nasional yang tangguh yang berarti nasionalisme menjiwai tiap kebijaksanaan ekonomi;

4) Koperasi merupakan soko guru perekonomian dan merupakan bentuk yang paling konkrit dari usaha bersama;

5) Adanya imbangan yang jelas dan tegas antara perencanaan di tingkat nasional dengan desentralisasi dalam pelaksanaan kegiatan ekonomi untuk menjamin keadilan sosial.

Menurut Emil Salim, ciri-ciri di atas dilengkapi dengan pengertian yang berdasarkan pada dokumendokumen UUD 1945 dan GBHN, dapat ditarik dari ciri-ciri system ekonomi Pancasila sebagai berikut (Purwandaya: 2017 dan Pasaribu, 2017: 8):

1) Peranan negara beserta aparatur ekonomi negara adalah penting, tetapi tidak dominan agar dicegah tumbuhnya sistem etatisme (serba negara). Peranan swasta adalah penting, tetapi juga tidak dominan agar dicegah tumbuhnya free fight liberalism. Dalam sistem ekonomi Pancasila, usaha negara dan swasta tumbuh berdampingan dengan perimbangan tanpa dominasi berlebihan satu terhadap yang lain.

2) Hubungan kerja antar lembaga-lembaga ekonomi tidka didasarkan pada dominasi modal seperti halnya dalam sistem ekonomi kapitalis. Juga tidak didasarkan atas dominasi buruh seperti halnya dalam sistem ekonomi komunis 
tetapi asas kekeluargaan, menurut keakraban hubungan antar manusia.

3) Masyarakat sebagai satu kesatuan memegang peranan sentral. Produksi dikerjakan oleh semua untuk semua di bawah pimpinan atau penilikan anggotaanggota masyarakat.

4) Negara menguasai bumi, air dan kekayaan alam yang terkandung dalam bumi dan yang merupakan pokok bagi kemakmuran rakyat

5) Tidak bebas nilai, bahkan sistem nilai inilah mempengaruhi kelakuan pelaku ekonomi. (Swasono: 2005).

Pada akhir-akhir ini banyak diperbincangkan mengenai system ekonomi kerakyatan. Seperti yang dikemukakan oleh pakar ekonomi kita Prof. Mubyarto bahwa system ekonomi kerakyatan tidaklah berbeda dengan apa yang disebut dengan system ekonomi Pancasila. Hanya lebih ditekankan pada sila ke 4 yakni "Kerakyatan yang dipimpin oleh hikmat kebijaksanaan dalam permusyawaratan

perwakilan (Pasaribu, 2017: 8).

Sistem Ekonomi Kerakyatan adalah Sistem Ekonomi Nasional Indonesia yang berasas kekeluargaan, berkedaulatan rakyat, bermoral Pancasila, dan menunjukkan pemihakan sungguhsungguh pada ekonomi rakyat. Syarat mutlak berjalannya sistem ekonomi kerakyatan yang berkeadilan sosial (Pasaribu, 2017: 8-9):
1) Berdaulat di bidang politik

2) Mandiri di bidang ekonomi

3) Berkepribadian di bidang budaya

Yang mendasari paradigma pembangunan ekonomi kerakyatan yang berkeadilan sosial :

1) Penyegaran nasionalisme ekonomi melawan segala bentuk ketidakadilan sistem

2) dan kebijakan ekonomi

3) Pendekatan pembangunan berkelanjutan yang multidisipliner dan multikultural

4) Pengkajian ulang pendidikan dan pengajaran ilmu-ilmu ekonomi dan sosial di sekolah-sekolah dan perguruan tinggi

Jika kita mengacu pada Pancasila dasar negara atau pada ketentuan pasal 33 UUD 1945, maka memang ada kata kerakyatan tetapi harus tidak dijadikan sekedar kata sifat yang berarti merakyat. Kata kerakyatan sebagaimana bunyi sila ke-4 Pancasila harus ditulis lengkap yaitu kerakyatan yang dipimpin oleh hikmat kebijaksanaan dalam permusyawaratan/perwakilan, yang artinya tidak lain adalah demokrasi ala Indonesia. Jadi ekonomi kerakyatan adalah (sistem) ekonomi yang demokratis. Pengertian demokrasi ekonomi atau (sistem) ekonomi yang demokratis termuat lengkap dalam penjelasan pasal 33 UUD 1945 yang berbunyi: "Produksi dikerjakan oleh semua untuk semua dibawah pimpinan atau penilikan anggota-anggota masyarakat. Kemakmuran masyarakat lah yang diutamakan bukan kemakmuran 
orang seorang. Sebab itu perekonomian disusun sebagai usaha bersama berdasar atas asas kekeluargaan. Bangun perusahaan yang sesuai dengan itu ialah koperasi." (Pasaribu, 2017: 9).

Perekonomian berdasar atas demokrasi ekonomi, kemakmuran bagi semua orang. Sebab itu cabang-cabang produksi yang penting bagi Negara dan yang menguasai hidup orang banyak harus dikuasai oleh negara. Kalau tidak, tampuk produksi jatuh ke tangan orang-orang yang berkuasa dan rakyat

yang banyak ditindasinya. Hanya perusahaan yang tidak menguasai hajat hidup orang banyak boleh ada di tangan orang-seorang. Bumi dan air dan kekayaan alam yang terkandung di dalam bumi adalah pokok-pokok kemakmuran rakyat. Sebab itu harus dikuasai oleh Negara dan dipergunakan untuk sebesar-besar kemakmuran rakyat. Tujuan yang diharapkan dari penerapan Sistem Ekonomi Kerakyatan (Pasaribu, 2017: 9):

1) Membangun Indonesia yang berdikiari secara ekonomi, berdaulat secara politik, dan berkepribadian yang berkebudayaan.

2) Mendorong pertumbuhan ekonomi yang berkesinambungan.

3) Mendorong pemerataan pendapatan rakyat.

4) Meningkatkan efisiensi perekonomian secara nasional.

Lima hal pokok yang harus segera diperjuangkan agar system ekonomi kerakyatan tidak hanya menjadi wacana saja:

1) Peningkatan disiplin pengeluaran anggaran dengan tujuan utama memerangi praktek Korupsi, Kolusi dan Nepotisme (KKN) dalam segala bentuknya.

2) Penghapusan monopoli melalui penyelenggaraan mekanisme persaingan yang berkeadilan (fair competition).

3) Peningkatan alokasi sumbersumber penerimaan negara kepada pemerintah daerah.

4) Penguasaan dan redistribusi pemilikan lahan pertanian kepada petani penggarap.

5) Pembaharuan UU Koperasi dan pendirian koperasikoperasi "sejati" dalam berbagai bidan usaha dan kegiatan. Yang perlu dicermati, peningkatan kesejahteraan rakyat dalam konteks ekonomi kerakyatan tidak didasarkan pada paradigma lokomatif, melainkan pada paradigma fondasi.

Dasar filosofis sistem ekonomi Indonesia adalah Pancasila dan dasar konstitusionilnya adalah UUD 1945 pasal 23, 27, 33, dan 34 (Rintuh: 2005). Dengan demikian maka sistem ekonomi Indonesia adalah sistem ekonomi yang berorientasi kepada Ketuhanan Yang Maha Esa (berlakunya etik dan moral agama, bukan materialisme); Kemanusiaan yang adil dan beradab (tidak mengenal pemerasan atau eksploitasi); Persatuan Indonesia 
(berlakunya kebersamaan, asas kekeluargaan, sosio-nasionalisme dan sosio-demokrasi dalam ekonomi); Kerakyatan (mengutamakan kehidupan ekonomi rakyat dan hajat hidup orang banyak); serta Keadilan Sosial (persamaan, kemakmuran masyarakat yang utama bukan kemakmuran orang-seorang) (Swasono, 2005).

Dari butir-butir di atas, keadilan menjadi sangat utama di dalam sistem ekonomi Indonesia. Keadilan merupakan titik-tolak, proses dan tujuan sekaligus. Pasal 33 UUD 1945 adalah pasal utama bertumpunya sistem ekonomi Indonesia yang berdasar Pancasila, dengan kelengkapannya, yaitu Pasal-pasal 18, 23, 27 (ayat 2) dan 34 (Pasaribu, 2017: 10).

Berdasarkan TAP MPRS XXIII/1966, ditetapkanlah butir-butir Demokrasi Ekonomi (kemudian menjadi ketentuan dalam GBHN 1973, 1978, 1983, 1988), yang meliputi penegasan berlakunya Pasal-Pasal 33, 34, 27 (ayat 2), 23 dan butir-butir yang berasal dari Pasal-Pasal UUDS tentang hak milik yuang berfungsi sosial dan kebebasan memilih jenis pekerjaan. Dalam GBHN 1993 butir-butir Demokrasi Ekonomi ditambah dengan unsur Pasal 18 UUD 1945. Dalam GBHN 1998 dan GBHN 1999, butir-butir Demokrasi Ekonomi tidak disebut lagi dan diperkirakan "dikembalikan" ke dalam PasalPasal asli UUD 1945 (Purwandaya: 2017).

Landasan normatif-imperatif ini mengandung tuntunan etik dan moral luhur, yang menempatkan rakyat pada posisi mulianya, rakyat sebagai pemegang kedaulatan, rakyat sebagai ummat yang dimuliakan Tuhan, yang hidup dalam persaudaraan satu sama lain, saling tolongmenolong dan bergotongroyong (Pasaribu, 2017: 10).

Dari landasan sistem ekonomi Indonesia sebagaimana dikemukakan di atas (Pancasila, UUD 1945, TAP MPRS No. XXIII/66 dan GBHN-GBHN 1973, 1978, 1983, 1988, 1998, 1999), jelas bahwa ekonomi Indonesia berpedoman pada ideology kerakyatan. Kerakyatan dalam sistem ekonomi mengetengahkan pentingnya pengutamaan kepentingan rakyat dan hajat hidup orang banyak, yang bersumber pada kedaulatan rakyat atau demokrasi. Oleh karena itu, dalam sistem ekonomi berlaku demokrasi ekonomi yang tidak menghendaki "otokrasi ekonomi", sebagaimana pula demokrasi politik menolak "otokrasi politik". Asas kekeluargaan yang brotherhood bukanlah asas keluarga atau asas kekerabatan yang nepotistik. Kebersamaan dan kekeluargaan adalah asas ekonomi kolektif (cooperativism) yang dianut Indonesia (Purwandaya: 2017 dan Pasaribu, 2017: 10).

Ada beberapa kelebihan dari sistem ekonomi pancasila antara lain sebagai berikut (Rainer: 2018):

1) Hak milik perorangan diakui dan digunakan dengan tidak bertentangan dengan hajat masyarakat. 
2) Potensi inisiatif dan kreasi masing-masing warga negara dikembangkan

sepenuhnya selama tidak merugikan untuk kepentingan umum.

3) Warga negara mempunyai kebebasan dan menentukan pekerjaan yang sesuai atau yang diinginkan.

4) Perekonomian dibuat sebagai upaya bersama terhadap asas kekeluargaan.

5) Cabang produksi yang penting untuk negara dan menguasai kepentingan hidup orang banyak dikuasai oleh Negara.

6) Bumi dan air dan kekayaan alam yang terkandung didalamnya dikuasai negara dan digunakan sebesarbesarnya untuk kemakmuran rakyat.

7) Fakir miskin dan anakanak terlantar dipelihara oleh Negara.
Kekurangan Sistem Ekonomi Pancasila. Terdapat ciri negatif yang hendaknya dihindari dalam sistem perekonomian karena sifatnya kontradiktif dengan nilai dan kepribadian bangsa Indonesia, yaitu (Rainer: 2018):
1) Sistem Free Fight Liberalism, yang menumbuhkan eksploitasi manusia dan bangsa lain.
2) Sistem Etatisme, negara sangat berperan dan juga mematikan potensi serta daya kreasi unit ekonomi di luar sektor Negara.
3) Pemusatan kekuatan ekonomi di suatu kelompok dalam bentuk monopoli yang merugikan masyarakat.

\section{F. Sitem Ekonomi Islam (Idiologi al-Qur'an dan Sunnah). \\ Ekonomi Islam memiliki ciri} sesuai idiologinya, yaitu Tauhid (Keesaan Tuhan), Bahwa Segala Sesuatu yang diciptakan Allah memiliki tujuan untuk ibadah dan pada Allahlah kita mempertanggung jawabkan segala perbuatan kita. Adl', Dalam Ekonomi Islam adl berate tidak mendzalimi dan tidak dzalimi. Nubuwwah (Kenabian), dalam menjalankan kegiatan perekonomian kita harus meneladani sifat-sifat nabi seperti Sidiq (komitmen untuk menegakan kebenaran), Amanah (dapat dipercaya karena kejujuran), Tabligh (menyampaikan kebenaran melalui suri tauladan sesuai dengan tuntutan 
situasi dan kondisi) dan Fathanah (Kecerdasan baik intelektual emosional dan spiritual). Khilafah (Pemerintahan), Khilafah berperan dalam menjamin perekonomian agar berjalan sesuai syariah dan tidak terjadi pelanggaran hak-hak manusia. Ma'ad (hasil), implikasi nilai ma'ad adalah bahwa motivasi para pelaku bisnis muslim adalah untuk mendapatkan keuntungan dunia dan akhirat (Zaki, 2017: 3).

Sedangkan ciri-ciri dan prinsip-prinsip Sistem Ekonomi Islam Multitype Ownership, dalam ekonomi islam berlaku system kepemilikan ganda, yakni mengakui bermacammacam kepemilikan, baik kepemilikan Induvidu, swasta maupun Negara. Freedom to Act, setiap muslim diperbolehkan bebas melakukan usaha perdagangan ( ekonomi ) asalkan aktifitas yang dilakukan tidak merusak dan mengandung riba ( tambahan yang didapat secara zalim ) , gharar ( ketidakpastian ) dan maysir ( perjudian ) dan penipuan. Social Justice, gabungan Nilai Khilafah dan ma'ad melahirkan prinsip social justice yang artinya dalam hal ini yaitu menjalankan bisnis harus atas dasar suka sama suka/ tidak saling mendzalimi (Zaki, 2017: 3).

Keunggulan Sistem Ekonomi Islam Dibanding Sistem Ekonomi Lainnya. Menurut Thomas Khun menyatakan bahwasanya setiap sistem ekonomi mempunyai inti paradigma. Inti paradigma ekonomi Islam bersumber dari Al-Quran dan Sunnah. Ekonomi Islam mempunyai sifat dasar sebagai ekonomi Rabbani dan Insani. Disebut
Ekonomi Rabbani karena sarat dengan arahan dan nilai-nilai Ilahiyah. Sedangkan ekonomi Insani karena ekonomi ini dilaksanakan dan ditujukan untuk kemakmuran manusia. (Qardhawi, 2004: 10). Menurut Qardhawi (2004: 10) sitem ekonomi Islam tidak berbeda dengan sistem ekonomi laiannya, dari segi bentuk, cabang, rincian, dan cara pengaplikasian yang beraneka ragam., tapi menyangkut gambaran global yang mencakup pokok-pokok petunjuk, kaidahkaidah pasti, arahan-arahan prinsip yang juga mencakup sebagian cabang penting yang bersifat spesifik ada perbedaannya. Hal itu karena sistem Islam selalu menetapkan secara global dalam masalah-masalah yang mengalami perubahan karena perubahan lingkungan dan zaman. Sebaliknya menguraikan secara rinci pada masalah-masalah yang tidak mengalami perubahan. Ada beberapa Karasteristik keunggulan sistem ekonomi Islam sebagaimana disebutkan dalam Al-Mawsu'ah Alilmiah wa al-amaliyah al-islamiyah yang diringkas sebagai berikut (Zaki, 2017: 4):

1) Harta Kepunyaan Allah dan Manusia Merupakan Khalifah Atas Harta

Karasteristik pertama ini terdiri dari 2 bagian yaitu : Pertama, semua harta baik benda maupun alat produksi adalah milik Allah Swt, firman Q.S. Al- Baqarah, ayat 284 dan Q.S.Al -Maai'dah ayat 17. Kedua, manusia adalah khalifah atas harta 


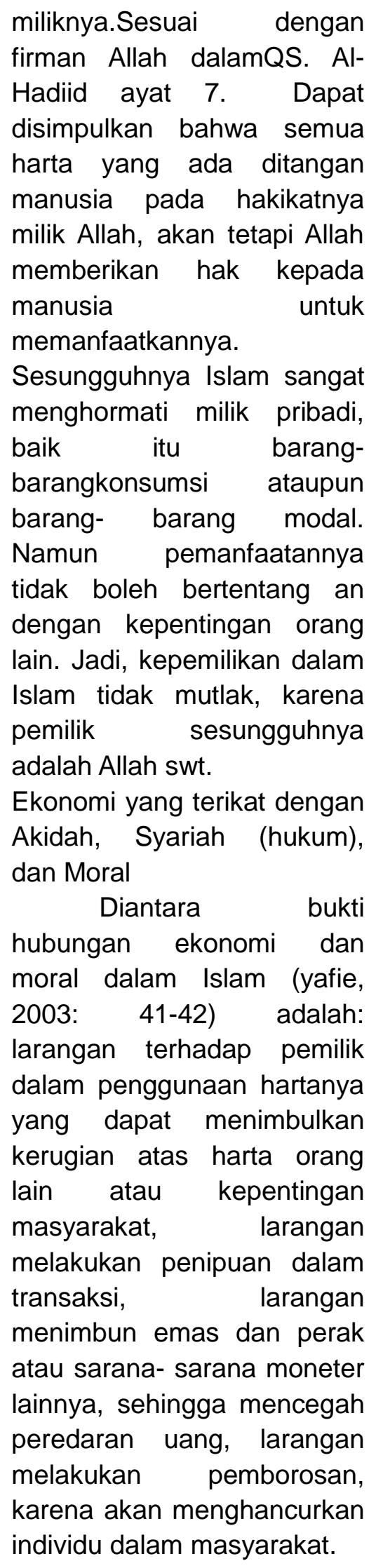

3) Keseimbangan antara

Kerohanian dan Kebendaan

Beberapa ahli Barat memiliki tafsiran tersendiri terhadap Islam. Mereka menyatakan bahwa Islam sebagai agama yang menjaga diri, tetapi toleran (membuka diri). Selain itu para ahli tersebut menyatakan Islam adalah agama yang memiliki unsur keagamaan (mementingkan segi akhirat) dan sekularitas (segi dunia). Sesungguhnya Islam tidak memisahkan antara kehidupan dunia dan akhirat.

4) Ekis Menciptakan Keseimbangan Kepentingan Individu danKepentingan umum

Arti keseimbangan dalam sistem sosial Islam adalah, Islam tidak mengakui hak mutlak dan kebebasan mutlak, tetapi mempunyai batasan- batasan tertentu, termasuk dalam bidang hak milik. Hanya keadilan yang dapat melindungi keseimbangan antara batasan- batasan yang ditetapkan dalam sistem Islam untuk kepemilikan individu dan umum. Kegiatan ekonomi yang dilakukan oleh seseorang untuk mensejahterakan dirinya, tidak boleh dilakukan dengan mengabaikan dan mengorbankan kepentingan orang lain dan masyarakat secara umum (Zaki, 2017: 5). 
5) Kebebasan Individu Dijamin dalam Islam Individu-individu dalam perekonomian Islam diberikan kebebasan untuk beraktivitas baik secara perorangan maupun kolektif untuk mencapai tujuan. Namun kebebasan tersebut tidak boleh melanggar aturan- aturan yang telah digariskan Allah SWT. Dalam Al-Qur'an maupun Al-Hadis. Dengan demikian kebebasan tersebut sifatnya tidak mutlat. Prinsip kebebasan ini sangat berbeda dengan prinsip kebebasan sistem ekonomi kapitalis maupun sosialis. Dalam kapitalis, kebebasan individu dalam berekonomi tidak dibatasi norma- norma ukhrawi, sehingga tidak ada urusan halal atau haram. Sementara dalam sosialis justru tidak ada kebebasan sama sekali, karena seluruh aktivitas ekonomi masyarakat diatur dan ditujukan hanya untuk negara.

6) Negara Diberi Wewenang Turut Campur dalam Perekonomian Islam

memperkenankan negara untuk mengatur masalah perekonomian agar kebutuhan masyarakat baik secara individu maupun sosial dapat terpenuhi secara proporsional. Dalam Islam negara berkewajiban melindungi kepentingan masyarakat ketidakadilan yang dilakukan oleh seseorang atau sekelompok orang, ataupun dari negara lain. Negara juga berkewajiban memberikan jaminan sosial agar seluruh masyarakat dapat hidup secara layak. Peran negara dalam perekonomian pada sistem Islam ini jelas berbeda dengan sistem kapitalis yang sangat membatasi peran negara. Sebaliknya juga berbeda dengan sistem sosialis yang memberikan kewenangan negara untuk mendominasi perekonomian secara mutlak.

7) Petunjuk Investasi

Tentang kriteria atau standar dalam menilai proyek investasi, al-Mawsu'ah Alilmiyahwa-al amaliyah alislamiyah memandang ada lima kriteria yang sesuai dengan Islam untuk dijadikan pedoman dalam menilai proyek investasi, yaitu:
a) Proyek yang baik menurut Islam.
b) Memberikan rezeki seluas mungkin kepada anggota masyarakat.
c) Memberantas kekafiran, memperbaiki pendapatan, dan kekayaan.
d) Memelihara dan menumbuhkembangkan harta.
e) Melindungi kepentingan anggota masyarakat.

8) Adanya Variable Zakat 


\begin{abstract}
Zakat adalah salah satu karasteristik ekonomi Islam mengenai harta yang tidak terdapat dalam perekonomian lain. Sistem perekonomian diluar Islam tidak mengenal tuntutan Allah kepada pemilik harta, agar menyisihkan sebagian harta tertentu sebagai pembersih jiwa dari sifat kikir, dengki, dan dendam (Zaki, 2017: 6).

9) Larangan Riba
\end{abstract}

Islam menekankan pentingnya memfungsikan uang pada bidangnya yang normal yaitu sebagai fasilitas transaksi dan alat penilaian barang. Diantara faktor yang menyelewengkan uang dari bidangnya yang normal adalah bunga (riba). Ada beberapa pendapat lain mengenai karasteristik ekonomi Islam, diantaranya dikemukakan oleh Marthon (2004) sebagaimana dikutip Febrianto (2018).

Menurutnya hal- hal yang membedakan ekonomi Islam secara operasional dengan ekonomi sosialis maupun kapitalis adalah :
a) Dialektika Nilai-nilai Spritualisme dan Materialisme
b) Kebebasan berekonomi
c) Dualisme Kepemilikan

\section{KESIMPULAN}

Sistem Ekonomi adalah suatu sistem yang mengatur serta menjalin hubungan ekonomi dengan antar manusia dengan seperangkat kelembagaan dalam tatanan kehidupan bermasyarakat atau bernegara. Hampir setiap negara memiliki sistem ekonomi sendiri. Paradigma pemikiran sebagai pilihan sistem ekonomi yang diterapkan di suatu negara tergantung pada kesepakatan bersama negara tersebut, sesuai dengan undangundang dasar yang dimiliki, falsafah dan ideologi negara dalam sistem perekonomiannya. sistem ekonomi adalah suatu sistem yang mengatur kondisi perekonomian suatu negara sesuai dengan kondisi kenegaraan dari negara itu sendiri. Sistem ekonomi kapitalis bersandar kepada pemilikan pribadi maupun swasta terhadap alat-alat produksi, kegiatan distribusi, maupun pertukaran. Sehingga tiga hal utama tersebut berada penuh di tangan swasta, sistem ini beridiologi Yahudi. Sistem ekonomi sosialis adalah kegiatankegiatan ekonominya mulai dari perencanaan, pelaksanaan, serta pengawasan dilakukan oleh pemerintah secara terpusat, sistem ini beridiologi Nasrani. Sistem ekonomi komunis adalah suatu sistem perekonomian di mana peran pemerintah sebagai pengatur seluruh sumber-sumber kegiatan perekonomian, sistem ini beridiologi Ateis. Sistem ekonomi Pancasila adalah sistem demokrasi ekonomi, sistem ini beridiologi Pancasila. Sistem ekonomi Islam adalah sistem ekonomi yang beridiologikan Tauhid Islam, Nubuwwah Muhammad saw (sifat wajib bagi nabi dan Rasul) dan Khilafah (kepemimpinan) serta Ma'ad (hasil). 


\section{DAFTAR PUSTAKA}

Agustiati, Sistem Ekonomi Kapitalisme (Jurnal Ekonomi ISSN 1411- 3341, 2015)

Agustiati, Sistem Ekonomi Kapitalisme, (Jurnal Academica, Volume 1 Nomor. 2, Palu: Universitas Tadulako, 2009)

Al-Kaaf, Abdullah Zakiy, Ekonomi dalan perspektif Islam. (Bandung: CV Pustaka Setia, 2012)

Amazine.co-Online Popular Knowledge. Kelebihan dan Kekurangan Sistem Ekonomi Kapitalis. 2017)

Ash-Shadr, Syahid Baqir, Keunggulan Ekonomi Islam. (Jakarata: Pustaka Zahra. Penerjemah, M. Hasem, 2012).

Asy'arie, Musa, Disampaikan dalam Focused Group Discussion Matakuliah Sejarah Pemikiran Ekonomi Islam, Pascasarjana (S3 Ekonomi Islam) UIN Sunan Kalijaga, Kamis, 15 Desember 2016)

Bawazier, Fuad, Sistem Ekonomi Pancasila: Memaknai Pasal 33 UUD 1945 (Jurnal Keamanan Nasional Vol. III, No. 2, November 2017)

Bhudianto, Wahyu, Sistem Ekonomi Kerakyatan Dalam Globalisasi Perekonomian (Jurnal Transformasi Vol.XIV No 22 Tahun 2012)

Boediono, Ekonomi Makro, Seri Sinopsis Pengantar IImu EkonomiNo. 2, Edisi, (Yogyakarta: BPFE, 1993)
Caporaso, A. James, Teori Teori Ekonomi Politik, (Yogyakarta: Pustaka Pelajar, 2008)

Chaudhry, Muhammad Sharif, Sistem Ekonomi Islam, Prinsip Dasar, (Jakarta: Kencana, 2012)

D.F. Griffith, What is Socialism? : A Symposium (London: Richards, 1984), dikutip oleh J. Wilczynski, The Economics of Socialism (1988)

Dumairy, Perekonomian Indonesia. (Jakarta: Erlangga, 2006)

Farida, Ai Siti, Sistem Ekonomi Indonesia, (Pustaka Setia, Bandung, 2011)

Febrianto, Aditya Trio, PrinsipPrinsip Ekonomi Islam .wibesiteonline http://adityatriofebrianto.blogs pot.co.id/.diakses24Februari2 018.

Grossman, Gregory, Sistem-sistem ekonomi. Cetakan ketiga (Jakarta: PT Bumi Aksara, 2015)

Hermanto, Bambang, Dasar Filosofis Pertumbuhan Ekonomi, Distribusi Dan Konsumsi Dalam Ekonomi Islam (AlFikra: Jurnal IImiah Keislaman, Vol. 10, No. 2, Juli-Desember 2011)

Indonesia, Bank, Perekonomian Global (BI: Bagian I Laporan Perekonomian Indonesia, 2013)

Kinasih, Rayi, Pengertian sistem ekonomi menurut para ahli besertamacam-macam sistem ekonomi, (2011). http://rarayiyikinasihsblog.blo 
gspot.com/2011/03/pengertia n-sistem-ekonomimenurutpara.html.diakses pada 14 Januari 2018.

Koto, Alaiddin, Ekonomi Islam Antara Peluang Dan Tantangan Ke Depan (Al-Fikra: Jurnal Ilmiah Keislaman, Vol. 4, No. 1, Januari-Juni 2005)

Latief, Dochak, Perbandingan sistem skonomi: islam, liberalisme, sosialisme.(Yogyakarta:

Yayasan penerbitan FKIS IKIP, 2004)

Ledi Trialdi, I Kadek Dian Sutrisna A. dan Joko Arif, Transformasi Sistem Ekonomi Indonesia Menuju Sistem Ekonomi Sosialisme Pasar (Buletin Ekonomi Moneter dan Perbankan, Juni 1999)

Mubyarto, Ekonomi Pancasila: Gagasan dan kemungkinan. (Jakarta: LP3ES, 2007)

Mujahidin, Akhmad, Pengentasan Kemiskinan Dalam Prespektif Ekonomi Islam (Al-Fikra : Jurnal IImiah Keislaman, Vol. 7, No. 1, Januari-Juni 2008)

Pangiuk, Ambok, Kepemilikan Ekonomi Kapitalis Dan Sosialis (Konsep Tauhid Dalam Sistem Islam) (Jurnal nalar Fiqih Jurnal Kajian Ekonomi Islam dan Kemasyarakatan, Volume 4, Nomor 2, Desember 2011)

Pasaribu, Rowland Bismark Fernando, Sistem Ekonomi (Universitas Gunadarma, 2017, Pertemuan 14, email:roawland.pasaribu@g mail.com)
Purwandaya, Budhi, Lestari Agusalim, Muhamad Karim, P. Setia Lenggono, Soenarto Soedarno, Subiakto Tjakrawerdaja, Sistem Ekonomi Pancasila (Jakarta: PT. Rajagarfindo, 2017)

Qardhawi, Yusuf, Peran Nilai dan Moral dalam Perekonomian Islam, (Jakarta : Rabbani Press, 2004)

Rainer, Dedi, Pengertian Sistem Ekonomi Pancasila, Ciri-Ciri, Kelebihan,

Kekuranga.wibesiteonline.htt $\mathrm{p}: / / \mathrm{www}$. spengetahuan.com/2 018/01/pengertian-sistemekonomi-pancasila-ciri-cirikelebihankekurangan.html.diakses23F ebruari2018.

Rintuh, Cornelis, Perekonomian Indonesia. (Yogyakarta: Liberty, 2005)

Roubini, Nouriel, Kapitalisme Yang Layak Suatu Cetak Biru Reformasi Ekonomi Kita (Jakarta: Friedrich-EbertStiftung Kantor Perwakilan Indonesia Jalan Kemang Selatan II No. 2A - Jakarta 12730|Indonesia, 2016)

Suaedih, Edih, Angga Yulira Putra, Imam Faozi, Unus Widiyansah Dan Rohmat, Sistem Ekonomi Komunis (Makalah Pengantar IImu Ekonomi Fakultas Teknik Program Studi Teknik Industri Universitas Pamulang Tangerang Selatan, 2016)

Subandi, Sistem Ekonomi Indonesia, (Jakarta: Alfabeta, 2012) 
Al-Fikra: Jurnal IImiah Keislaman, Vol. 17, No. 1, Januari - Juni, 2018 (97-129)

Supriyanto, Memahami Cara Bekerja

Sistem Perekonomian (Jurnal

Ekonomi \& Pendidikan, Volume 6 Nomor 2, November 2009)

Supriyanto, Memahami Cara Bekerja

Sistem Perekonomian (Jurnal

Ekonomi \& Pendidikan, Volume 6 Nomor 2, November 2009)

Suroso, Perekonomian Indonesia (Jakarta: PT. Gramedia Pustaka Utama, 2014)

Suroso, Perekonomian Indonesia. (Jakarta: PT. Gramedia Pustaka Utama, 2004)

Swasono, Sri Edi, Sistem ekonomi dan demokrasi ekonomi. Jakarta: Universitas Indonesia (UI-Press), 2005)

Syahpawi, Ekonomi Melayu Dalam Tatanan Ekonomi Islam (Jurnal Al-Fikrah Dosen Ekonomi Islam Fakultas Syari'ah dan IImu Hukum UIN Suka Riau)

T. Gilarso, Pengantar IImu Ekonomi Makro. (Yogyakarta:

Kanisius, 2014)

Tho'in, Muhammad, Konsep Ekonomi Islam Jalan Tengah (Kapitalis-Sosialis) (Jurnal Jurnal IImiah Ekonomi Islam Vol. 01 No. 03, November 2015)
Trialdi, Ledi, I Kadek Dian Sutrisna A. dan Joko Arif, Transformasi Sistem Ekonomi Indonesia Menuju Sistem Ekonomi Sosialisme Pasar (Buletin Ekonomi Moneter dan Perbankan, Juni 1999)

Winardi, IImu Ekonomi (AspekAspek Sejarahnya), (Bandung: PT Citra Aditya Bakti, 1990)

Wiranata, Eka, Sistem Ekonomi Liberalis dan Komunis,Wisesiteonline.http:/ /kantiekito.blogspot.co.id/201 0/11/sistem-ekonomiliberalis-dankomunis.html.diakses.24Febr uari2018.

Yetti, Febri Delmi, Bank : Studi Komparatif Antara Ekonomi Konvensional Dan Ekonomi Islam (Al-Fikra: Jurnal IImiah Keislaman, Vol. 11, No. 1, Januari-Juni 2012)

Zaki, Khozin, Sistem Ekonomi Islam (Makalah Program Studi Bahasa Inggris Departemen Bahasa Seni Dan Manajemen Budaya Sekolah Vokasi Universitas Gadjah Mada Yogyakarta, 2017) 